\title{
LAND COVER CHANGES IN NORTHEAST CHINA FROM THE LATE 1970S TO 2004
}

\author{
SHEN, Z. ${ }^{1} *-$ LU, C. ${ }^{1}-$ YIN, R. $^{2}-$ QI, J. ${ }^{3}$ \\ ${ }^{1}$ College of Environmental and Resource Sciences, Zhejiang University, \\ 388 Yuhangtang Road, Hangzhou 310058, China \\ (phone: 86-571-88982997; fax: 86-571-88982997) \\ ${ }^{2}$ Department of Forestry, Michigan State University, \\ 110 Natural Resources, East Lansing, MI 48824, USA \\ (phone: 1-517-4323352; fax: 1-517-4321143) \\ ${ }^{3}$ Center for Global Change and Earth Observations \& Department of Geography, \\ Michigan State University, East Lansing, MI48823, USA, 1405 S. Harrison Road, Room 218, \\ (phone: 1-517-3538736; fax: 1-517-3532932) \\ *Corresponding author \\ e-mail: zhqshen@zju.edu.cn \\ (Received $19^{\text {th }}$ July 2011; accepted $29^{\text {th }}$ January 2013)
}

\begin{abstract}
This paper presents a quantitative analysis of land cover changes in northeast China from the late 1970s to 2004 using remote sensing and the Geographic Information System. Land covers are mapped into six classes and nine sub-classes from multi-temporal Landsat MSS, TM and ETM+ images and SRTM DEM data. It is found that while forestland and wetland were greatly reduced until 2000 due to farming expansion and urbanization, spurred by population growth, their decline trends have been revered most recently. Meanwhile, built-up land has kept increasing. Further, the land cover changes occurred primarily in areas with low elevation and gentle slope. These results suggest that the forest and wetland protection and restoration projects have taken effect. However, there remains a long way to go before the ecosystems are greatly recovered and can function in the way that society expects.
\end{abstract}

Keywords: ecological restoration, land cover change, northeast China, digital elevation model, Landsat MSS/TM/ETM+

\section{Introduction}

In recent decades, land use and land cover change (LUCC) has become an important part of global change research because of its interaction with climate, ecosystems, biogeochemical cycles and human activities (Xiao et al., 2006). The work of many investigators has shown that LUCC affects the global system in various ways, including atmospheric composition, regional climate, soil quality, hydrology, and biodiversity (Xu et al., 2007; Turner et al., 2007). Humans are the main force behind the global conversion of land cover (Kuemmerle et al., 2006), and their ecological and environmental influence has been steadily increasing.

Remote sensing can provide spatially consistent data sets that cover large areas with both high spatial detail and temporal frequency, and it is accepted as a "unique view" of the spatial and temporal dynamics of the LUCC processes. Therefore, remote sensing techniques have been widely used in detecting and monitoring land cover change at various scales (Xiao et al., 2006; Keuchel et al., 2003). The goal of this paper is to assess the land cover change in northeast China using remote sensing and GIS techniques. While we will focus on the change since the late 1990s when various forest 
and wetland protection and restoration projects were launched, we intend to trace the regional land cover change back to the late 1970s to put it in the proper context.

Due to its broad and repetitive coverage, Landsat has provided the scientific community with valuable imagery that can be utilized for detecting terrestrial land cover conditions and tracking vegetation dynamics, agricultural activity, urban growth, and surface hydrology (Alrababah and Alhamad, 2006). Further, its thermal band measures the emission of energy from the earth's surface, and it can thus be used as an indicator of land cover type based on recorded temperatures (Southworth, 2004). The post-classification method of change detection, which compares two or more separately classified images of different dates, is commonly used (Dewidar, 2004; Yuan et al., 2005).

China's tremendous population explosion, economic growth, and urbanization have caused major problems of resource depletion and ecosystem degradation (Liu and Diamond, 2005; Yin et al., 2005). To tackle these problems, the government has recently initiated a series of ecological restoration programs ( $\mathrm{Xu}$ et al., 2006). It is interesting and important to detect the induced land cover change of these programs and to relate the change to the policy initiatives in a timely manner. In so doing, not only will it make it possible for the science community to assess the potential impacts of these initiatives on ecosystem functions, but it will also enable us to provide much needed feedback to the agencies regarding the effectiveness of their policies.

While there have been many studies of the LUCC in China, most of them dealt with changes before 2000 (Jiang, 2002; Tang et al., 2005; Wang et al., 2005; Xiao et al., 2006; Xu et al., 2007; Zha et al., 2008). The LUCC in China after 2000 is rarely examined. In order to examine this period, it is necessary for us to acquire and interpret images available for the most recent past. In this paper, we select ten counties in northeast China as a study area because of its significance as a primary natural forest and wetland region. Our results show that while forestland and wetland were greatly reduced until 2000 due to farming expansion and urbanization, driven by population growth, their decline trends have been reversed most recently. Moreover, the land cover changes occurred mainly in areas with low elevation and gentle slope. These findings suggest that the forest and wetland protection and restoration projects have been effective. However, there is a long way to go before the ecosystems are greatly recovered and can function in a manner that society expects.

\section{Study area}

The study area is located in Heilongjiang province of northeast China. It includes 10 counties with a total area of about $29,000 \mathrm{~km}^{2}$, and ranges from $45^{\circ} 32^{\prime} 18^{\prime \prime} \mathrm{N}$ to $47^{\circ} 45^{\prime} 8^{\prime \prime} \mathrm{N}$ latitude and from $128^{\circ} 14^{\prime} 24^{\prime \prime} \mathrm{E}$ to $132^{\circ} 33^{\prime} 31^{\prime \prime} \mathrm{E}$ longitude. Its elevation is between 23 and 1307 meters above sea level. The northeast part belongs to the Sanjian Plain and is the lowest part in the study area, whereas the middle and southern parts are hilly and mountainous (Fig. 1). This area has a temperate, humid to sub-humid continental monsoon climate. The annual temperatures are $21-22^{\circ} \mathrm{C}$ (average maximal), $1.4-4.3^{\circ} \mathrm{C}$ (mean), and $-18^{\circ} \mathrm{C}$ (average minimal). Mean annual precipitation is $500-600$ $\mathrm{mm}$, and $80 \%$ of all rainfall occurs between May and September. The frost-free period is $120-140$ days.

Prior to 1950, the region was endowed with primary natural forests and wetland. From the 1950s to the late 1990s, however, a lot of the forestland and wetland was 
cleared for farming and timber (Yin et al., 2008). Since then, the central government has invested heavily in protecting the natural resources and restoring the ecosystems. While it is true that the environmental conditions have significantly improved in recent years, little has been done to assess to what extent the resource conservation projects have made a difference.

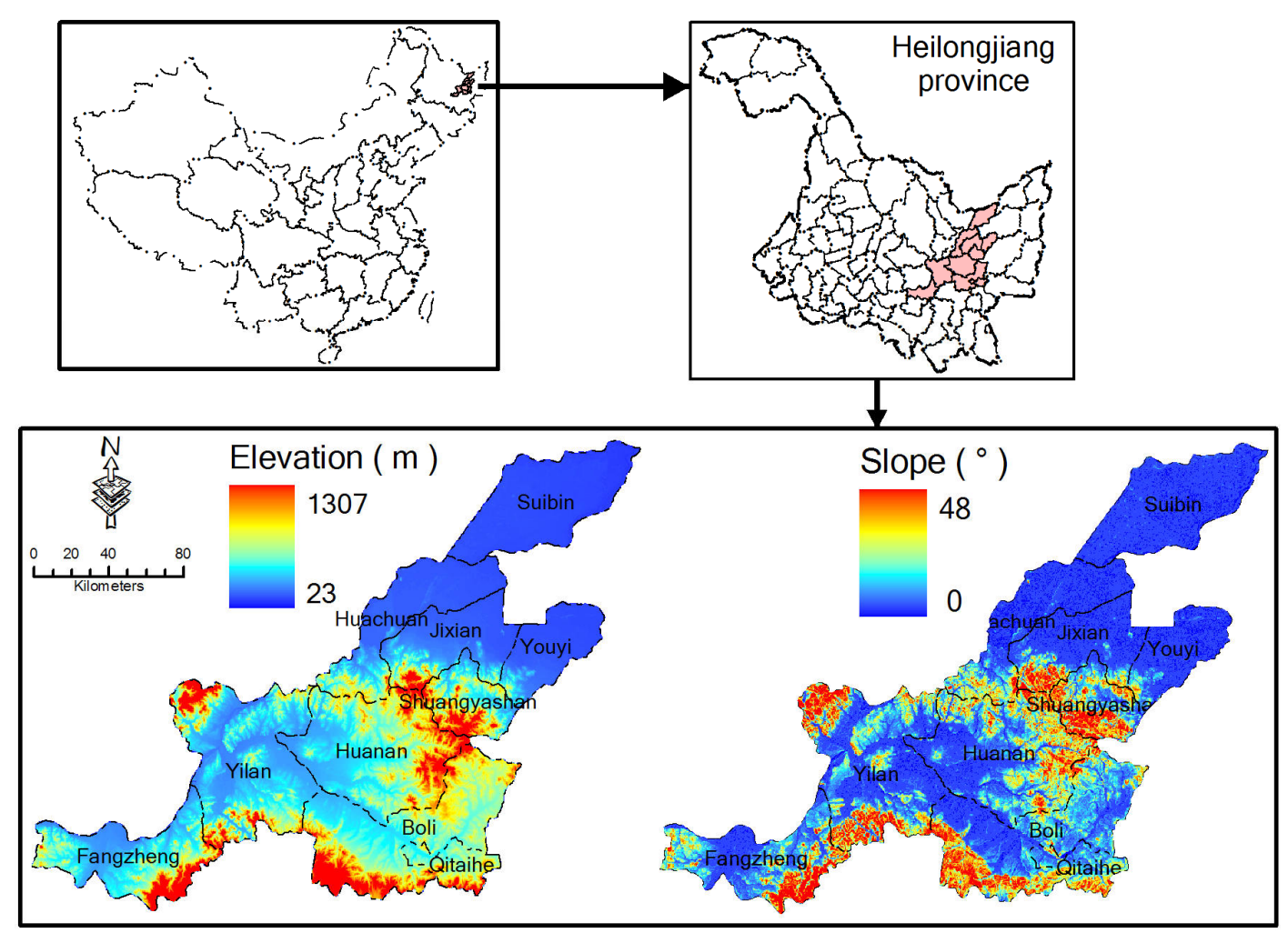

Figure 1. Location of the study area and its elevation and slope

\section{Materials and methods}

\section{Landsat imagery}

The Landsat images used in this study cover four points of time from the late 1970s to 2004. They include one set of MSS images for the late 1970s (hereafter, 1977), two sets of TM images for around 1990 (hereafter, 1990) and 2004, and one set of ETM+ images for around 2000 (hereafter, 2000). Each set has three images to cover the entire study area. The path, row, and acquired date for each scene are listed in Table 1. Notice that due to quality concerns, images for a given year may not be available; a common practice in this circumstance is to assemble them around a given year as closely as possible (Xiao et al., 2006; Jarvis et al., 2006). Also, notice that because of the quality deterioration of ETM+ images for 2004, TM images are used.

The MSS, TM, and ETM+ images for the first three points of time were downloaded from the Global Land Cover Facility site (http://glcf.umiacs.umd.edu), and they were georeferenced and rectified by the GLCF to UTM projection zone 52 and WGS84 datum with a spatial resolution of $57,28.5$, and 28.5 meters, respectively. Their TM6 images were re-sampled to match the resolution of other bands using the nearest- 
neighbor method. The TM images for 2004 were ordered from China Remote Sensing Satellite Ground Station, and they were geo-encoded and matched to the ETM+ images one by one with a total RMS error of less than 0.5 pixels using the image-to-image registration method. Then, they were re-sampled to 30 meters using the nearestneighbor method. Nearly all of the Landsat images are free of cloud. Finally, all sets of images were masked using the boundary of study area.
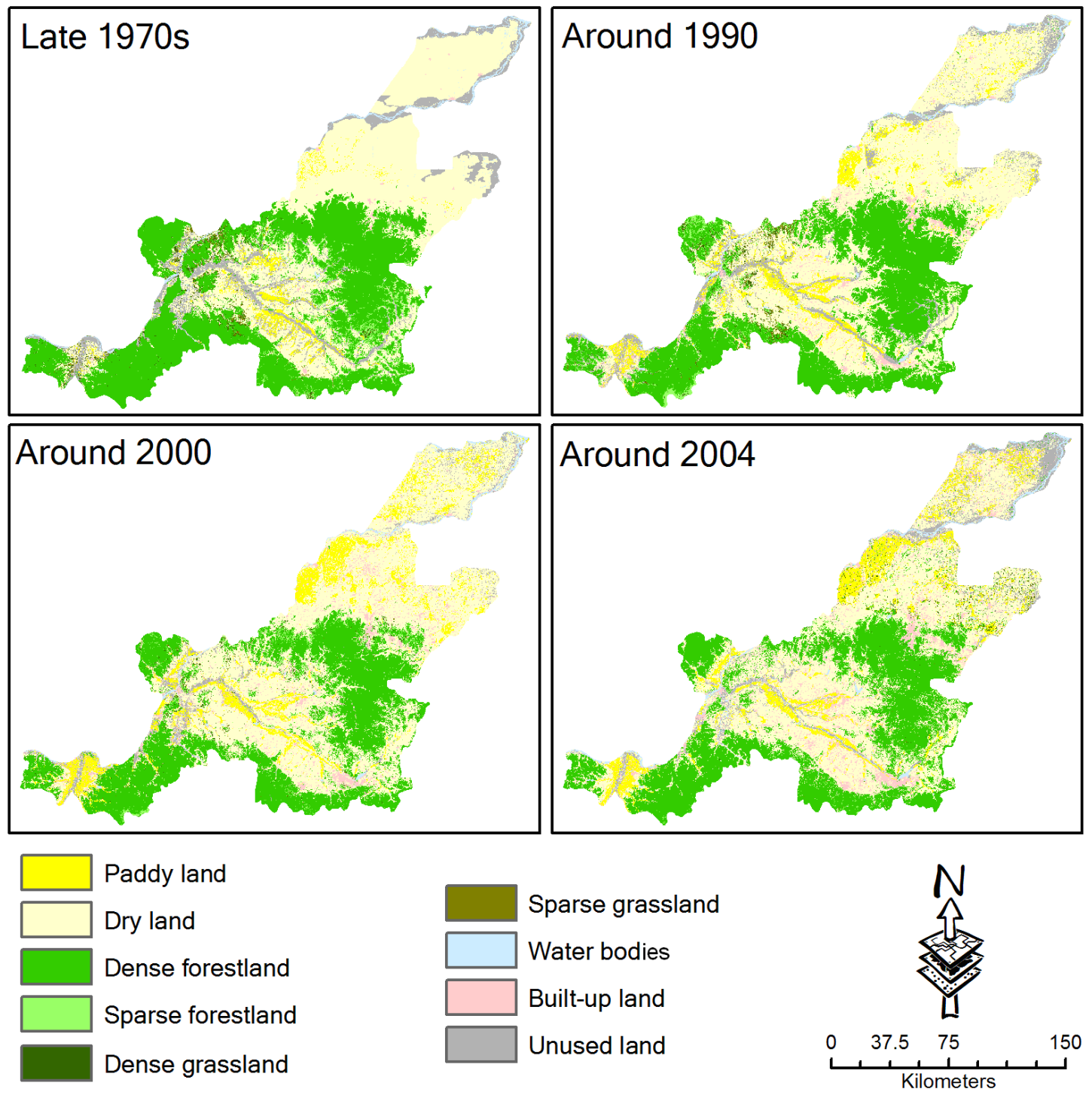

Figure 2. Maps of land covers in the study area

\section{Elevation data}

Topography is a fundamental geophysical variable that contains valuable information about the geodynamic and climatic history of a region (Coblentz and Riitters, 2004). It can be used in ecology, hydrology, agriculture, and many other fields as a means of explaining and predicting processes through modeling. It has also been used as a supplementary source of information for land cover classification. In addition, slope and 
aspect data produced from a coarse spatial resolution digital elevation model (DEM) can be integrated with multi-spectral data for land cover analysis (Nguyen et al., 2005).

Detailed and accurate DEM information can be generated from remote sensing systems, such as SPOT and ASTER, and finer differences in elevation can be obtained with airborne laser-scanners. NASA recorded most of the world's topography in the Shuttle Radar Topographic Mission (SRTM), and these data have been available for nearly the entire globe. An evaluation test indicated that if only cartography with scales above 1:25,000 (i.e., 1:50,000 and 1:100,000) is available, it is better to use the SRTM DEMs. The SRTM DEMs can be used for terrain derivatives (slope, aspect, landscape classifications, etc.) as well (Jarvis et al., 2004). However, some regions may miss data because of a lack of contrast in the radar image due to presence of water, or excessive atmospheric interference. These data holes are especially concentrated around rivers, lakes, and steep areas. This non-random distribution of holes impedes the potential use of SRTM data and has been the subject of a number of innovative algorithms for "filling-in" through spatial analysis techniques. In this study, the post-processing 3 arc second SRTM DEM data were acquired from CGIAR-CSI (the Consortium for Spatial Information of the Consultative Group for International Agricultural Research) web site by a geographic projection with the WGS84 horizontal datum and EGM96 vertical datum (Jarvis et al., 2006). The non-data holes in the original DEM were filled with the help of available auxiliary DEM data through an interpolative technique within an Arc/Info AML model, from which the slope information was derived. The DEM and slope data were masked using the region boundary of study area.

Table 1. Brief information for Landsat imagery used in the study

\begin{tabular}{c|c|c|c|c}
\hline Date & Late 1970s & Around 1990 & Around 2000 & Around 2004 \\
\hline Type of sensor & MSS & TM & ETM+ & TM \\
& $124-27$ & $115-27$ & $115-27$ & $115-27$ \\
Path \& row & $124-28$ & $115-28$ & $115-28$ & $115-28$ \\
& $125-28$ & $116-28$ & $116-28$ & $116-28$ \\
& 1978.08 .24 & 1991.06 .25 & 2000.08 .12 & 2004.06 .12 \\
Acquired date & 1976.05 .27 & 1993.09 .02 & 2000.08 .12 & 2004.06 .12 \\
& 1976.07 .03 & 1994.05 .23 & 2001.06 .03 & 2004.08 .22 \\
\hline
\end{tabular}

\section{Pre-processing and classification}

A land-use map at a scale of 1:500,000 was obtained for the selection of training data and validation of classification results. The map covers the whole Heilongjiang province around 1995. Even though it was developed following the old version of the Chinese land-use classification system (Chinese National Land Resource Survey Committee, 1984) and its resolution is a bit coarser, it is still very helpful.

The whole image pre-processing included two steps. First, MSS 4-7 or TM/ETM 15,7 were transformed by Principal Component Analysis (PCA) method and the first $n$ principal components that accounted for over $98 \%$ of the variance in the images based on Eigen-value analysis were extracted. Second, the extracted PC images, elevation, slope and thermal band (only for TM and ETM images) were stacked together. Before classifying land cover, a two-tier hierarchical classification scheme was set up with the assistance of long-term field knowledge gained from geography, vegetation, and land cover in northeastern China. There are six primary classes: farmland, forestland, 
grassland, built-up land, water bodies, and unused land. Farmland, forestland, and grassland are further divided into certain sub-classes (Table 2).

Table 2. Description of the land cover classification system used in this study

\begin{tabular}{|c|c|c|}
\hline Level 1 class & Level 2 class & Description \\
\hline Farmland & Paddy land & $\begin{array}{l}\text { Farmland mainly used for growing paddy rice and lotus roots with } \\
\text { guaranteed water source or irrigation facilities, including paddy field } \\
\text { rotated with dryland crops. }\end{array}$ \\
\hline & Dry land & $\begin{array}{l}\text { Rain-fed farmland without irrigation; dry farmland with irrigation; } \\
\text { land mainly for growing vegetables; and fallow land. }\end{array}$ \\
\hline Forestland & $\begin{array}{l}\text { Dense } \\
\text { Sparse }\end{array}$ & $\begin{array}{l}\text { Natural or plantation forest with canopy cover }>40 \% \text {. } \\
\text { Natural or plantation forest with canopy cover } \leq 40 \% \text {. }\end{array}$ \\
\hline Grassland & $\begin{array}{l}\text { Dense } \\
\text { Sparse }\end{array}$ & $\begin{array}{l}\text { Natural or artificial grassland with canopy cover }>20 \% \\
\text { Natural or artificial grassland with canopy cover } \leq 20 \%\end{array}$ \\
\hline Water bodies & & $\begin{array}{l}\text { Natural water system and land for irrigation facilities, including } \\
\text { river, lake, pond, glacier, reservoir, etc. }\end{array}$ \\
\hline Built-up land & & $\begin{array}{l}\text { Residence, transportation network, and other buildings, including } \\
\text { land for urban occupation, etc. }\end{array}$ \\
\hline
\end{tabular}

The widely used supervised classification method, Maximum Likelihood Classification (MLC), was employed. That is, the ancillary land cover map was overlaid on the images, and the training site data were collected by means of the on-screen selection of the polygons. The NDVI (Normalized Difference Vegetation Index) images derived from the original images were used to help the identification of sub-classes of forestland and grassland based on the MLC. Due to satellite instruments and other considerations, the images in each set were classified individually. The classified results of images in each set were then combined for further analysis.

Table 3. Summary of accuracy assessment for image classification

\begin{tabular}{|c|c|c|c|c|c|c|c|c|c|c|c|c|}
\hline \multirow[b]{2}{*}{$\begin{array}{c}\text { Level } 1 \\
\text { class }\end{array}$} & \multicolumn{4}{|c|}{ Producer's accuracy $(\%)$} & \multicolumn{4}{|c|}{ User's accuracy (\%) } & \multicolumn{4}{|c|}{ Kappa coefficient } \\
\hline & \begin{tabular}{|c|} 
Late \\
$1970 \mathrm{~s}$
\end{tabular} & \begin{tabular}{|c|} 
Around \\
1990
\end{tabular} & $\begin{array}{c}\text { Around } \\
2000\end{array}$ & $\begin{array}{c}\text { Around } \\
2004\end{array}$ & $\begin{array}{l}\text { Late } \\
1970 \mathrm{~s}\end{array}$ & $\begin{array}{c}\text { Around } \\
1990\end{array}$ & $\begin{array}{l}\text { Around } \\
2000\end{array}$ & $\begin{array}{l}\text { Around } \\
2004\end{array}$ & \begin{tabular}{|c|} 
Late \\
$1970 \mathrm{~s}$
\end{tabular} & $\begin{array}{c}\text { Around } \\
1990\end{array}$ & $\begin{array}{c}\text { Around } \\
2000\end{array}$ & $\begin{array}{l}\text { Around } \\
2004\end{array}$ \\
\hline Far & 94.93 & 87.54 & 91.30 & 91.77 & 90.35 & 91.07 & 89.15 & 93.43 & 0.8295 & 0.8521 & 0.7578 & 0.8612 \\
\hline Fore & 95.87 & 21 & & 93 & 96.03 & & 5 & & 0.9 & 55 & 20 & 218 \\
\hline Gras & 30.00 & 70.00 & & 21.05 & 41.38 & 71.79 & 77.27 & 47.06 & 0.3977 & 21 & 0.7673 & 0.4568 \\
\hline water & 100.00 & 83.33 & & 96.88 & 95.00 & 88.24 & 96.67 & 93 & 0.9494 & 09 & 0.9660 & 0.9381 \\
\hline $\begin{array}{l}\text { Built-up } \\
\text { land }\end{array}$ & 44.44 & 74.36 & 68.57 & 81.67 & 100.00 & 67 & 63.16 & 52.69 & 1.0000 & 0.6657 & 0.6135 & 0.5072 \\
\hline Unused land & 72.85 & 7 & & 69 & 82.09 & 88 & 5 & 44 & 0.8 & 95 & 92 & 0.6052 \\
\hline Overall & 91.13 & 88.87 & 87.87 & 89.27 & 91.13 & 88.87 & 87.87 & 89.27 & 0.8561 & 0.8285 & 0.7934 & 0.8233 \\
\hline
\end{tabular}

The resultant land cover maps were assessed for accuracy in ERDAS IMAGINE ver. 9.1. About 1500 pixels were randomly selected from each set of classified outcomes in the study area. A confusion matrix was first generated, and then the producer's and user's accuracy as well as the Kappa coefficient for each class and the whole image set were derived.

In determining land cover change, a cross-tabulation detection method was adopted. A change matrix was produced, showing the overall land cover changes and gains and 
losses in each class. And the change matrix reveals the main types of changes in the study area (Wang et al., 2005).

\section{Results}

The derived accuracy measures for each land cover class and the whole image set are summarized in Table 3. While some classes have a relatively low degree of classification accuracy, those major ones, such as forestland and farmland, have a very high degree of accuracy. Further, the overall degree of accuracy is quite high. So, it can be said that the results are reasonably accurate (Alrababah and Alhamad, 2006).

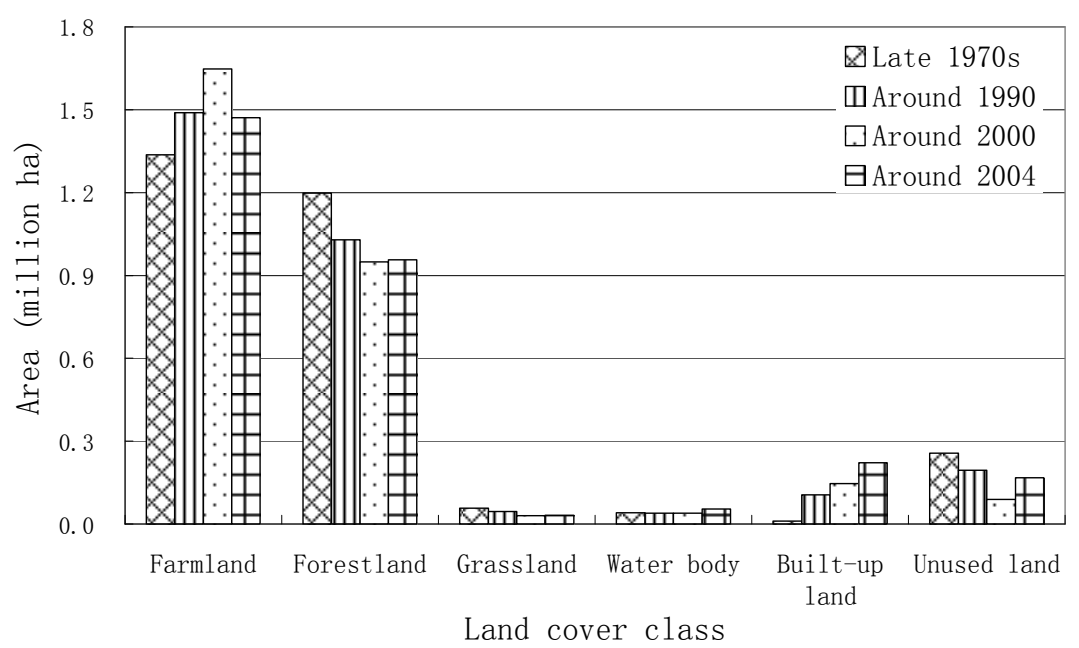

(1) Land corver classes

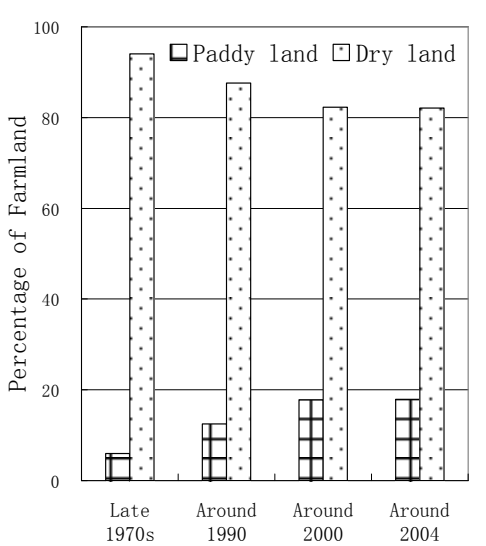

(2) Farmland

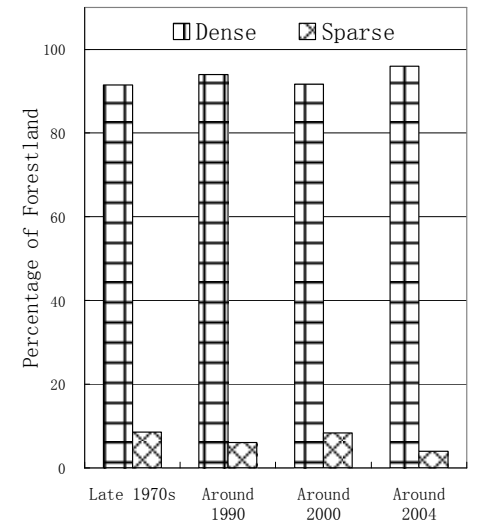

(3) Forestland

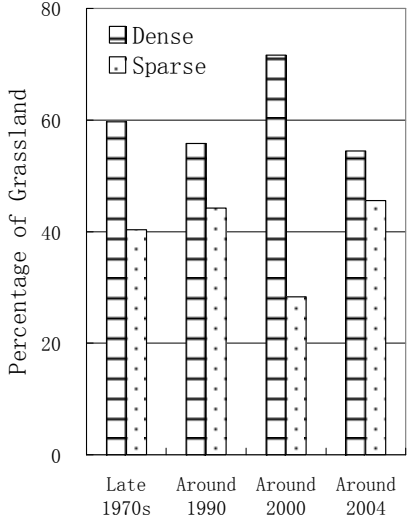

(4) Grassland

Figure 3. Areas of land covers (1) and proportion of sub-classes for farmland (2), forestland (3), and grassland (4)

The land cover maps for the four points of time are shown in Figure 2. The overall land cover changes from the late 1970s to 2004 are illustrated in Figure 3. It can be seen that farmland and forestland are the two largest land cover classes in the study area. Farmland took up 46.13-56.75 \% of the total area, and forestland accounted for 32.69- 
$41.31 \%$. But built-up land had the largest rate of change in the whole study period. The area of farmland increased steadily from the late 1970s to 2000, and then it declined from 2000 to 2004.

Table 4. Land cover transition over time in the study area (unit: ha)

\begin{tabular}{|c|c|c|c|c|c|c|c|}
\hline & \multirow[b]{2}{*}{$\begin{array}{l}\text { Land cover } \\
\text { classes }\end{array}$} & \multicolumn{6}{|c|}{ Late 1970s } \\
\hline & & $\begin{array}{c}\text { Farmlan } \\
\text { d }\end{array}$ & Forestland & Grassland & $\begin{array}{l}\text { Water } \\
\text { bodies }\end{array}$ & $\begin{array}{c}\text { Built-up } \\
\text { land }\end{array}$ & Unused land \\
\hline \multirow{7}{*}{$\begin{array}{c}\text { Around } \\
1990\end{array}$} & Farmland & 1158357 & 143955 & 40568 & 6375 & 2201 & 134951 \\
\hline & Forestland & 32888 & 980366 & 5667 & 463 & 654 & 2679 \\
\hline & Grassland & 946 & 41699 & 2445 & 109 & 19 & 562 \\
\hline & Water bodies & 3721 & 1208 & 299 & 28217 & 10 & 6523 \\
\hline & Built-up land & 72150 & 12972 & 4785 & 683 & 7288 & 8138 \\
\hline & Unused land & 68327 & 15914 & 2988 & 4356 & 97 & 102804 \\
\hline & \multirow{7}{*}{$\begin{array}{c}\text { Farmland } \\
\text { Forestland } \\
\text { Grassland } \\
\text { Water bodies } \\
\text { Built-up land } \\
\text { Unused land }\end{array}$} & \multicolumn{6}{|c|}{ Around 1990} \\
\hline \multirow{7}{*}{$\begin{array}{c}\text { Around } \\
2000\end{array}$} & & 1327921 & 104707 & 26938 & 4661 & 49210 & 134152 \\
\hline & & 31009 & 895773 & 12659 & 65 & 3322 & 6192 \\
\hline & & 6927 & 17185 & 4903 & 86 & 950 & 1135 \\
\hline & & 4482 & 508 & 151 & 31442 & 844 & 2225 \\
\hline & & 72257 & 7365 & 579 & 3194 & 49794 & 13573 \\
\hline & & 46321 & 2090 & 566 & 597 & 2025 & 37370 \\
\hline & \multirow{7}{*}{$\begin{array}{c}\text { Farmland } \\
\text { Forestland } \\
\text { Grassland } \\
\text { Water bodies } \\
\text { Built-up land } \\
\text { Unused land }\end{array}$} & \multicolumn{6}{|c|}{ Around 2000} \\
\hline \multirow{6}{*}{$\begin{array}{l}\text { Around } \\
2004\end{array}$} & & 1273770 & 92105 & 12318 & 1963 & 53835 & 35995 \\
\hline & & 101503 & 832828 & 13917 & 236 & 4819 & 2780 \\
\hline & & 24310 & 4571 & 183 & 15 & 2043 & 665 \\
\hline & & 11946 & 541 & 202 & 33128 & 5543 & 3014 \\
\hline & & 120873 & 16508 & 4310 & 1039 & 71973 & 7663 \\
\hline & & 114634 & 1705 & 212 & 3145 & 8499 & 38780 \\
\hline
\end{tabular}

From Table 4, it is found that the expansion of farmland came mostly from forestland, unused land, and grassland. While the dominant part of the farmland was dry land, the proportion of paddy land increased from the late 1970s to 2000 and then stabilized. The unused land, more precisely wetland in this area, was reclaimed and converted to paddy land. The largest proportion of farmland is located in the area of slopes less than $2^{\circ}$ and elevations less than 200 meters, and it is noticeable that cropland in this range declined from 2000 to 2004, because of the conversion to built-up land, grassland, or unused land (Fig. 4 and 5).

The trend of change for forestland from the late 1970 to 2000 was opposite to that of farmland. That is, while farmland increased significantly, forestland declined rapidly. But forestland slightly increased from 2000 to 2004. Conversion of forestland to farmland was the major driver for the decrease of forestland, as shown in Figure 3. The proportions of sub-classes in forestland were stable from the late 1970s to 2000, and then changed slightly. The dominant sub-class of forestland is dense forest, and its proportion was over $91 \%$ in the entire study period. The forest restoration and conservation projects launched in the late 1990s might be a cause for the slight increase of forestland from 2000 to 2004 . The forestland was mostly located in the zone of medium slope $\left(2-15^{\circ}\right)$ and elevation (200-500 meters), and its change occurred in the zone with low to medium slope (less than $15^{\circ}$ ) and elevation (less than 500 meters); this trend of change coincided with the overall change of forestland in the flat and low elevation area (less than $2^{\circ}$ and 200 meters), and it was stable in the areas of steep slope (more than $15^{\circ}$ ) and high elevation (over 500 meters). 


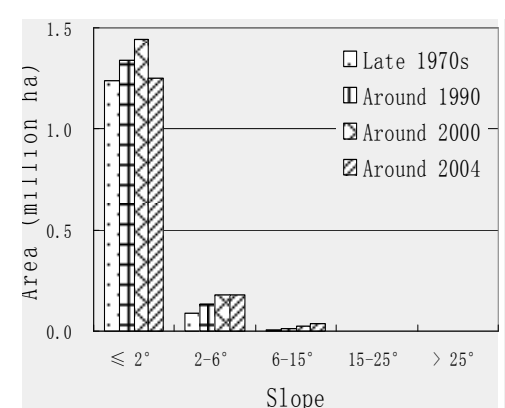

(1) Farmland

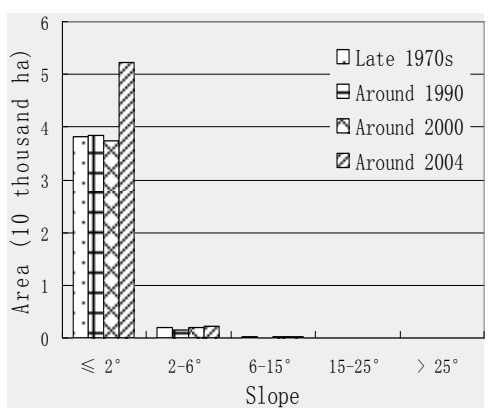

(4) Water bodies

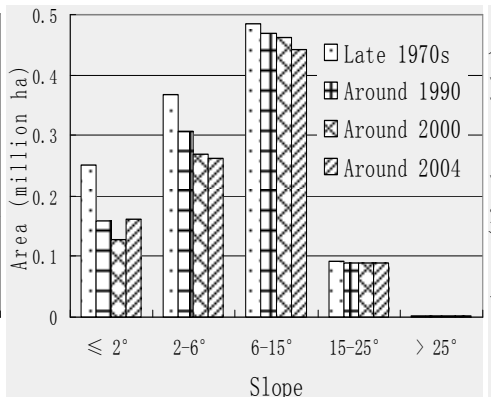

(2) Forestland

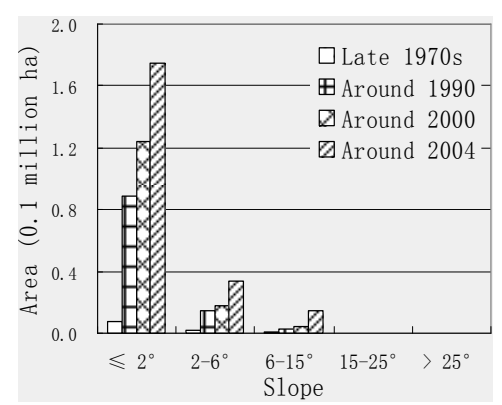

(5) Built-up land

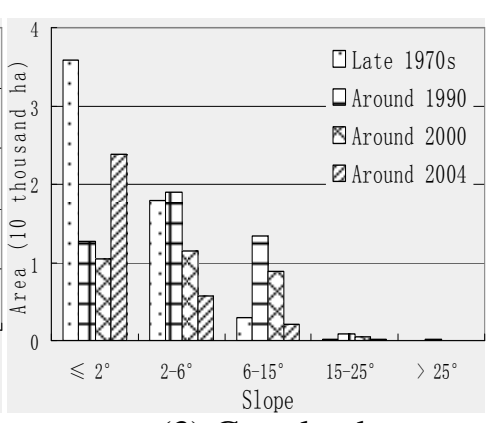

(3) Grassland

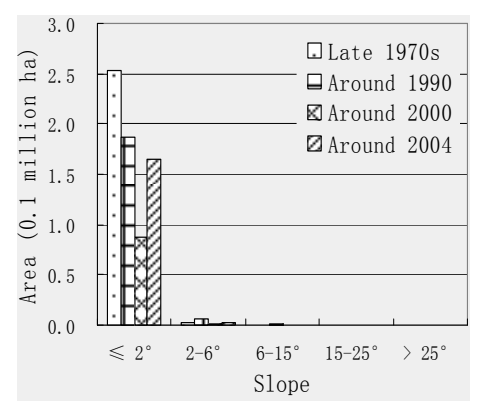

(6) Unused land

Figure 4. Distribution of land covers in different slope zones over time

The percentage of grassland was very low in this area and it had the similar trend of change to forestland. The major conversion for grassland was between farmland, forestland, and itself. Grassland was located mostly in mountainous areas and inside or near forest before 2000, but its major part shifted to low altitude area and plains and was converted from farmland by 2004.

The cause of the shift might be the policy of protecting wetland and grassland since late 1990s. Most of the grassland was located below 500 meters and the main change for grassland occurred in the area of low elevation (less than 200 meters) and gentle slope (less than $2^{\circ}$ ). Likewise, nearly all bodies of water were located in flat areas (less than $2^{\circ}$ ) below 200 meters.

From the late 1970s to 2004, the area of built-up land increased about 20 times due to the population growth and life style change. Most of the expanded built-up land came from farmland, which is easy to distinguish on the land cover maps (Fig. 2). The main part of the built-up land was in the area of low elevation (less than 200 meters) and gentle slope (less than $2^{\circ}$ ). The unused land, or wetland, declined from the late 1970s to 2000, and increased thereafter. The cause for the decline was that the wetland was reclaimed as farmland to meet the increasing demand of food and other products, and the recent increase might be due to the wetland protection policy (SFA, 2007). Most of the unused land was in areas below 200 meters and with low slope (less than $2^{\circ}$ ). 


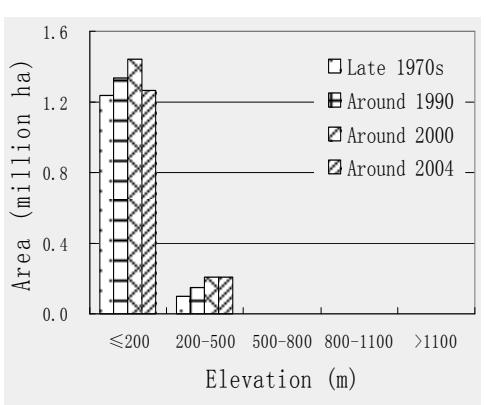

(1) Farmland

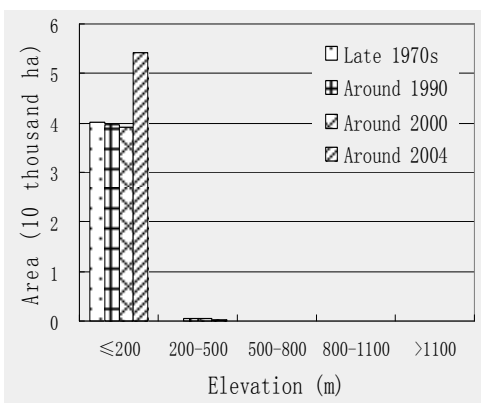

(4) Water bodies

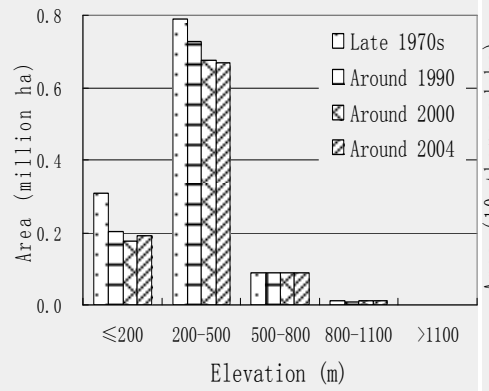

(2) Forestland

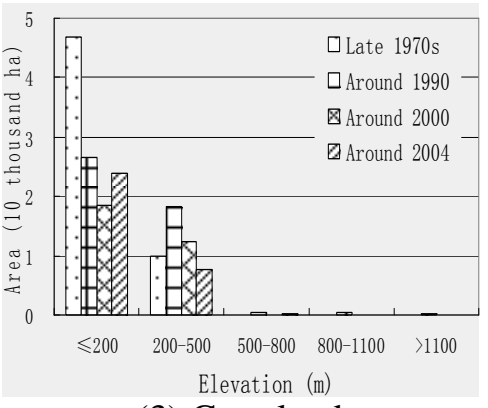

(3) Grassland

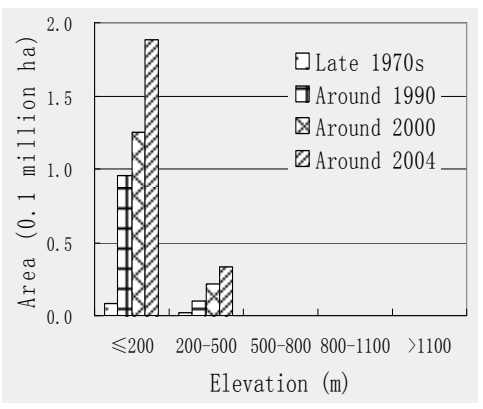

(5) Built-up land

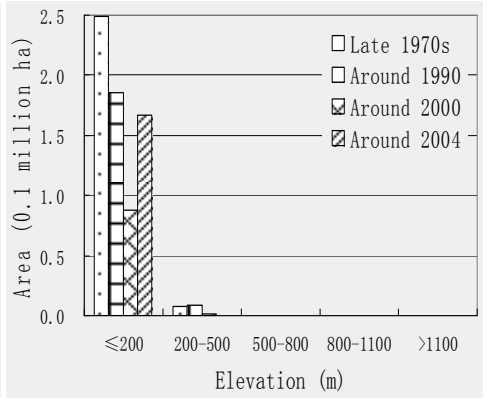

(6) Unused land

Figure 5. Distribution of land covers in different altitudinal zones over time

\section{Conclusions and discussion}

Using multi-temporal Landsat imagery and GIS-related techniques, this study has produced fairly accurate land cover maps for ten counties in northeast China, which is one of the focal areas of the country's recent forest and wetland protection and restoration initiatives. These maps enabled us to assess the land cover characteristics and changes over time. Our results indicate that from the late 1970s to 2004, the study area experienced some significant land cover changes, induced by human activities, agricultural policy, and ecological restoration. Year 2000 was a turning point of the land use trends. Before that time, farmland expanded persistently by encroaching on the natural forests, grassland, and wetland, due to population increase and agricultural growth. This led to the depletion of natural resources and degradation of ecosystems as well as reduced economic benefits to farming (Tong, 2003). However, since the forest restoration and wetland protection projects were launched in the late 1990s, the declining trend of forestland was reversed and a large part of the farmland was converted to forestland and wetland. Also, built-up land experienced a continuous increase in the study area, which is typical across the country, given the demographic and economic trends.

While we are satisfied with the accuracy of our results, they can be improved. First, although the terrain and thermal information was considered in the classification and the spectral similarity of land cover classes caused errors, more adequate contextual knowledge should be considered in the classification in order to tackle the 'confused' pixels and minimize the error. This will lead to a more accurate assessment of the land cover change. Second, ecological, political and economic factors should be incorporated into the driving forces analysis of LUCC. Finally, taking year 2000 as a turning point, we may derive more detailed land cover information before and after it so as to benefit 
the analysis of land cover change and its causes and effects. These ideas are being pursued currently.

Acknowledgements. This research was supported by the U.S. National Science Foundation as part of the research (An Integrative Impact Evaluation of China's Ecological Restoration Programs, 9/1/20068/30/2009) at Michigan State University. Image classification work benefited from the research assistance of Brain Walters.

\section{REFERENCES}

[1] Alrababah, M.A., Alhamad, M.N. (2006): Land use/cover classification of arid and semiarid Mediterranean landscapes using Landsat ETM. - International journal of remote sensing 27: 2703-2718.

[2] Chinese National Land Resource Survey Committee (1984): Chinese National Technical Standard for Land Use Survey, China. - Agricultural Press, Beijing (in Chinese).

[3] Coblentz, D.D., Riitters, K.H. (2004): Topographic controls on the regional-scale biodiversity of the south-western USA. - Journal of Biogeography 31: 1125-1138.

[4] Dewidar, K. (2004): Detection of land use/land cover changes for the northern part of the Nile delta (Burullus region), Egypt. - International journal of remote sensing 25(20): 4079-4089.

[5] Jarvis, A., Rubiano, J., Nelson, A., Farrow, A., Mulligan, M. (2004): Practical use of SRTM data in the tropics - Comparisons with digital elevation models generated from cartographic data. - Working Document no. 198, Cali, International Centre for Tropical Agriculture (CIAT): 32.

[6] Jarvis, A., Reuter, H.I., Nelson, A., Guevara, E. (2006): Hole-filled SRTM for the globe Version 3. - Available from the CGIAR-CSI SRTM 90m Database: http://srtm.csi.cgiar.org.

[7] Jiang, Q. (2002): LUCC and accompanied soil degradation in China from 1960's to 1990's. - Journal of Geoscience Research of Northeast Asia 5(1): 62-71.

[8] Keuchel, J., Naumann, S., Heiler, M., Siegmund, A. (2003): Automatic land cover analysis for Tenerife by supervised classification using remotely sensed data. - Remote sensing of environment 86: 530-541.

[9] Kuemmerle, T., Radeloff, V.C., Perzanowski, K., Hostert, P. (2006): Cross-border comparison of land cover and landscape pattern in Eastern Europe using a hybrid classification technique. - Remote sensing of environment 103: 449-464.

[10] Liu, J.G., Diamond, J. (2005): China's environment in a globalizing world. - Nature 435: 1179-1186.

[11] Nguyen, M.Q., Atkinson, P.M., Lewis, H.G. (2005): Superresolution mapping using a Hopfield neural network with LIDAR data. - IEEE Geoscience and Remote Sensing Letters 2: 366-370.

[12] Southworth, J. (2004): An assessment of Landsat TM band 6 thermal data for analyzing land cover in tropical dry forest regions. - International journal of remote sensing 25: 689-706.

[13] State Forestry Administration (SFA) (2007): The State Forestry statistics (in Chinese).

[14] Tang, J., Wand, L., Zhang, S. (2005): Investigating landscape pattern and its dynamics in Daqing, China. - International journal of remote sensing 26(11): 2259-2280.

[15] Tong, C., Hall, C.A.S., Wang, H. (2003): Land use change in rice, wheat and maize production in China (1961-1998). - Agriculture, Ecosystems \& Environment 95(2-3): 523-536. 
[16] Turner, II.B.L., Lambin, E.F., Reenberg, A. (2007): The emergence of land change science for global environmental change and sustainability. - Proceedings of the National Academy of Sciences USA 104(52): 20666-20671.

[17] Wang, Z., Zhang, B., Zhang, S., Li, X., Liu, D., Song, K., Li, J., Li, F., Duan, H. (2005): Changes of land use and of ecosystem service values in Sanjiang plain, northeast China. Environmental Monitoring and Assessment 112: 69-91.

[18] Xiao, J., Shen, Y., Ge, J., Tateishi, R., Tang, C., Liang, Y., Huang, Z. (2006): Evaluating urban expansion and land use change in Shijiazhuang China, by GIS and remote sensing. - Landscape and urban planning 75: 69-80.

[19] Xu, C., Liu, M., An, S., Chen, J.M., Yan, P. (2007): Assessing the impact of urbanization on regional net primary productivity in Jiangyin county, China. - Journal of environmental management 85: 597-606.

[20] Yin, R., Yin, G., Zhang, L. (2008): China's ecological restoration: The programs, implementation, and challenges. - Working paper (MSU Department of Forestry).

[21] Yuan, F., Sawaya, K., Loeffelholz, B., Bauer, M. (2005): Land cover classification and change analysis of the Twin Cities (Minnesota) Metropolitan Area by multitemporal Landsat remote sensing. - Remote sensing of environment 98: 317-328.

[22] Zha, Y., Liu, Y., Deng, X. (2008): A landscape approach to quantifying land cover changes in Yulin, Northwest China. - Environment monitor assessment 138: 139-147. 